\title{
EFFICACY OF SMARTPHONE-COMPATIBLE OPTICAL INSTRUMENT FOR ASSESSING MELANOCYTIC NEVI FOR MALIGNANCY
}

Gaydina TA $\bowtie$, Dvornikova EG

Pirogov Russian National Research Medical University, Moscow, Russia

Early detection of melanocytic nevus progression to malignant melanoma is a pressing concern. Traditionally, patients with multiple melanocytic nevi (MMN) are monitored for extended periods of time and excisional biopsies are performed on individual suspicious melanocytic nevi (MN). This approach is costly and tremendously time-consuming for both doctors and patients. The aim of this study was to evaluate the efficacy of a smartphone-compatible optical instrument in the assessment of MN for malignancy. Seven patients aged 43 to 65 years with MMN on the trunk and upper/lower extremities were followed-up for 4 years. Dermoscopy images of MN were taken and analyzed using a Handyscope smartphone-compatible optical system operated at 20x magnification and a Handyscope3 application. A total of $74 \mathrm{MN}$ were surgically removed during the follow-up period. None of the patients had melanoma. The results of dermoscopy image analysis generated by the convolutional neural network coincided with histopathology findings in all cases. The optical Handyscope system demonstrated its efficacy in assessing MN for malignancy. Al can be used for primary screening of MMN dermoscopy images. However, histopathological verification of the diagnosis is still needed.

Keywords: melanocytic nevus, artificial intelligence, mobile application, skin biopsy, early melanoma detection

Author contribution: both authors equally contributed to this manuscript.

Compliance with ethical standards: the study was approved by the Ethics Committee of Pirogov Russian National Research Medical University (Protocol № 201 dated October 21, 2020); all patients gave voluntary consent to surgery.

$\triangle$ Correspondence should be addressed: Tatiana A. Gaydina

Ostrovityanova, 1, Moscow, 117997; doc429@yandex.ru

Received: 11.09.2020 Accepted: 25.09.2020 Published online: 27.10.2020

DOI: $10.24075 /$ brsmu.2020.065

\section{ЭФФЕКТИВНОСТЬ ИСПОЛЬЗОВАНИЯ ОПТИЧЕСКОЙ СИСТЕМЫ СМАРТФОНА ДЛЯ ОЦЕНКИ ЗЛОКАЧЕСТВЕННОСТИ МЕЛАНОЦИТАРНЫХ НЕВУСОВ}

Т. А. Гайдина $џ$, Е. Г. Дворникова

Российский национальный исследовательский медицинский университет имени Н. И. Пирогова, Москва, Россия

Ранняя диагностика злокачественной трансформации меланоцитарных невусов в меланому кожи (МК) является актуальной проблемой современной медицины. Общепризнанная тактика ведения пациентов с множественными меланоцитарными невусами кожи (ММНК) представляет собой динамическое наблюдение с проведением эксцизионной биопсии отдельных онкологически подозрительных или меланомоопасных меланоцитарных невусов кожи (МНК). Данная тактика требует дорогостоящего оборудования и огромных временных затрат врача и пациента. Целью работы было оценить эффективность использования оптической системы смартфона для определения злокачественности меланоцитарных невусов. Семь пациентов в возрасте 43-65 лет с ММНК на коже туловища и конечностей находились под наблюдением в течение четырех лет. Получение дерматоскопических микроснимков и оценку злокачественности МНК проводили при помощи оптического устройства Handyscope с 20-кратным увеличением, сопряженного со смартфоном под управлением мобильного приложения Handyscope3. За период наблюдения пациентам было удалено 74 МНК, МК не было обнаружено ни в одном случае. Оценка злокачественности всех удаленных 74 МНК, проведенная сверточной нейронной сетью, совпала с результатами гистологических исследований. Оптический адаптер к смартфону показал эффективность в диагностике злокачественности МНК. Для скрининговой первичной диагностики дерматоскопических изображений ММНК возможно использовать искусственный интеллект (ИИ), однако необходимо гистологическое исследование для верификации диагноза.

Ключевые слова: меланоцитарный невус кожи, искусственный интеллект, мобильные приложения, биопсия кожи, ранняя диагностика меланомы

Вклад авторов: авторы внесли равнозначный вклад в работу.

Соблюдение этических стандартов: исследование одобрено этическим комитетом РНИМУ имени Н. И. Пирогова (протокол № 201 от 21 октября 2020 г.); все пациенты подписали добровольное информированное согласие на проведение оперативного лечения.

$\triangle$ Для корреспонденции: Татьяна Анатольевна Гайдина

ул. Островитянова, д. 1, г. Москва, 117997; doc429@yandex.ru

Статья получена: 11.09.2020 Статья принята к печати: 25.09.2020 Опубликована онлайн: 27.10.2020

DOI: $10.24075 /$ vrgmu.2020.065

Skin neoplasms can be evaluated using portable smartphonecompatible instruments and artificial intelligence (Al) algorithms. Such systems are a real time-saver for both the physician and the patient. They are also a good aid in monitoring melanocytic nevi (MN). To this day, progression of benign MN to malignant melanoma $(\mathrm{MM})$ remains understudied; therefore, with most MN health professionals should be watchful for any worrying signs. Statistically, in 2018 skin cancer was the most incident type of malignancy in the Russian population, amounting to 12.6 or $14.4 \%$ of cancers depending on whether malignant melanoma was excluded or included in the analysis. In Russia,
MM-associated mortality increased by $11.19 \%$ between 2008 and 2018 [1]. At the same time, according to the American Cancer Society, the number of deaths from MM in the USA was decreasing by $6.1 \%$ in men and $6.3 \%$ in women every year from 2013 to 2017, whereas the annual incidence of MM was growing by $2.2 \%$ in men and $1.9 \%$ in women [2]. Life expectancy of patients with MM largely depends on how advanced the disease is at the time of treatment initiation; grim figures suggest that early detection strategies existing in Russia need improving: in 2017, only one in 3 MM diagnoses was the result of active screening. In 2016-2017, stage IV 
MM was initially diagnosed in $19.0 \%$ of melanoma patients. This is a disturbing figure given that such tumors are visible to the naked eye [3]. Early detection of skin neoplasms (SN) can be significantly improved by optical instruments that are compatible with a smartphone and can be operated using a mobile application.

Risk factors for MM include excessive exposure to UV radiation, sunburns during childhood, Fitzpatrick skin types I and II, DKN2A gene mutations, the presence of 10 or more dysplastic nevi or over 100 multiple melanocytic nevi (MMN), a past history of skin cancer, and familial melanoma [4-6]. A combination of these factors increases the risk for MM. Patients with increased risk for MM are advised to undergo total body photography and digital dermoscopy once every 3-6 months; the obtained MN images should be analyzed with $\mathrm{Al}$, and excisional biopsies should be performed on suspicious lesions [7-9]. Patients with MNS (one of risk factors for MM) are recommended to have regular skin checkups once or twice; examination should be performed using noninvasive diagnostic techniques. With digital dermoscopy, a dermatologist can track changes occurring in MN over time and analyze them using $\mathrm{Al}$, thereby improving the quality of diagnosis [10-12]. All noninvasive methods for early MM detection can be arbitrarily classified into the following groups:

Group 1, total body photography for preliminary diagnosis that can be performed at a non-specialist clinic;

Group 2, evaluation of suspicious MN that can potentially progress to melanoma;

Group 3, evaluation of suspicious MN that can potentially progress to melanoma at a specialist clinic, including the extent of surgery for their removal [13].

Smartphone-compatible optical systems for dermoscopy imaging are a novel promising method of noninvasive MN diagnostics. Total body photography requires costly spaceconsuming equipment, whereas smartphone optical adapters are portable and convenient. Smartphones are affordable gadgets that can be used for taking, storing and sharing dermoscopy images or other medical data in case a second opinion is needed [14].

Patients with MMN should be carefully examined for possible changes in the existing nevi and closely monitored for the development of de novo lesions. However, it may still be difficult to spot the first signs of malignization even when more than one noninvasive diagnostic technique is applied. Unexperienced dermatologists are not always able to accurately interpret dermoscopy findings. This might result in overdiagnosis and unnecessary surgical interventions, on the one hand, and delayed melanoma diagnosis, on the other. Telediagnostics can help with difficult cases and save time for both patients and doctors. The rapid evolution of high technology and the digitalization of the medical field create a new, efficient environment for public health workers and improve the quality of medical care. The vigorous development of portable diagnostic devices makes it possible to monitor the broad range of clinically significant parameters of the human body. The aim of this study was to evaluate the efficacy of a smartphone-compatible optical system in diagnosing malignant melanocytic nevi.

\section{METHODS}

We followed up 4 male and 3 female patients aged 43-65 years (mean age being 51.14 years) over the course of 4 years. The following inclusion criteria were applied: male/female sex; age of 18 years or older; MMN on the trunk and/or extremities.
Exclusion criteria: age under 18 years; decompensated chronic conditions. MN were defined as multiple if a patient had over $100 \mathrm{MN}$. A total of $875 \mathrm{MN}$ were detected and examined during the entire follow-up period. Of them, $74 \mathrm{MN}$ were surgically removed. To take dermoscopy images and evaluate MN for malignancy, a smartphone-compatible Handyscope optical instrument with 20x magnification (FotoFinder; Germany) and a mobile Handyscope3 application were used. Handyscope3 is essentially a convolutional neuronal network trained on a large dataset of images of histologically confirmed malignancies.

Conveniently, high-quality dermoscopy images can be obtained with a digital smartphone camera, which is a great aid in practical clinical work. However, without an additional lens and adequate lighting, a smartphone camera cannot ensure the uniformity of shooting conditions and the sufficient amount of detail at high resolution. From a large selection of optical systems available on the market, we chose a Handyscope. The manufacturer has developed an Al-based application for evaluating and storing dermoscopy images. In difficult cases, the image can be uploaded to a second opinion service, where it can be evaluated by experienced dermoscopy experts.

\section{RESULTS}

In all patients, MMN were localized predominantly to the trunk $(n=699 ; 79.89 \%)$, upper $(n=117 ; 13.37 \%)$ and lower $(n=59$; $6.74 \%)$ extremities. The highest number of $\mathrm{MN}(n=183$, including 3 dysplastic nevi) was observed in a 65-year-old female patient; this woman received the maximum number of surgical excisions for her MN $(n=25)$ over the course of 4 years. The smallest number of $\mathrm{MN}(n=126)$ was observed in a 45-year-old man; in total, he had $5 \mathrm{MN}$ removed. The highest number of suspicious nevi was detected during primary examinations in the first year of observation (47 MN; $63.5 \%$ ). In the follow-up period, the patients visited a dermatologist twice a year; during each visit, the patients underwent digital dermoscopy with a smartphone and an optical attachment. The obtained images were analyzed by Al in the Handyscope3 application; $\mathrm{Al}$ assessed the photographed moles for malignancy on the scale from 0 to 1 . Values from 0.5 and 1 were interpreted as suspicious for malignancy, whereas values from 0 to 0.2 suggested a benign lesion. The risk of developing $\mathrm{MM}$ was explained to the patients; they were also strongly advised to have a checkup with a dermatologist twice a year. All patients were recommended to avoid direct sunlight, always use a maximum protection sunscreen and to give up on tanning at tanning salons. Patients with suspicious lesions were referred to an oncologist for deciding on the treatment strategy and evaluating the need for biopsy. According to the protocol proposed by the International Agency for Research on Cancer (IARS), the following clinical features of dysplastic nevi suggest the risk of melanoma: diameter over $5 \mathrm{~mm}$, irregular pigmentation patterns, asymmetry, irregular borders, peripheral hyperemia. According to the classic $A B C D$ criteria, none of our patients had MM. However, 5 patients had dysplastic nevi (totaling to 10), and in another 2 patients an equivocal diagnosis could not be established based on dermoscopy findings. All MN were analyzed by the mobile application, and all patients were referred to an oncologist.

Surgical excision of MN was performed by an oncologist at a specialist facility. In some cases, it was the patients who insisted on surgery because their nevi caused esthetic problems or were constantly subjected to mechanical irritation. Prior to surgery, the patients underwent dermoscopy, and the nevi were photographed. Either excisional or shave biopsies 
were performed under infiltration anesthesia; the biopsied specimens were subjected to a histopathological examination. Fig. 1 shows stages of the diagnostic procedure and the Albased assessment for malignancy.

In total, $74 \mathrm{MN}$ were removed. None of the patients was found to have MM. Results of the Al-based malignancy assessment coincided with histopathology findings in all cases. Ten (13.5\%) nevi excised from 5 patients were histologically confirmed to be dysplastic. In 35 cases (47.3\%) histopathology findings were suggestive of intradermal melanocytic nevi. Nine $(12.2 \%)$ melanocytic nevi were found to be of combined type. Two lesions $(2.7 \%)$ were Sutton's nevi. One lesion (1.6\%) was a simple lentigo. In 17 cases (22.97\%) of benign nevi, patients insisted on their surgical removal. Most of the excised nevi were localized to the trunk (60 MN; $81.1 \%$ ), followed by upper (8 MN; 10.8\%) and lower (6 MN; 8.1\%) extremities (Fig. 2).

Postoperatively, the patients complained of occasional itching and tenderness in the area of hypertrophic scar formation and some found scarring esthetically distressing. Such patients were prescribed topical medications for scar management.

\section{DISCUSSION}

There are no robust data on the epidemiology of MN. The terminology used to define $\mathrm{MN}$ is conflicting, and only malignant $\mathrm{SN}$ are covered by statistical analysis. Retrospective studies of digitized biopsies can improve our understanding of MN prevalence but so far this type of analysis is limited to a few regions [15]. There are a lot of different terms to describe $\mathrm{MN}$ at risk for progressing to melanoma [16]. In 1978, Clark described 2 families with MMN and high frequency of MN malignization. This condition was referred to as the $\mathrm{B}-\mathrm{K}$ mole syndrome, where $\mathrm{B}$ and $\mathrm{K}$ are the initials of the affected families.

According to some estimates, MN progress to melanoma in 4 to $54.2 \%$ cases $[17,18]$. There are MN with unknown potential for malignancy [19]. Patients with MMN are at risk for melanoma; the risk is the higher, the more lesions the patient has. It increases 7 -fold for patients who have 100 or more borderline nevi, as compared to those who have only 15 simple nevi [4]. The risk of melanoma also increases in patients with MMN and dysplastic nevi [5]. Nevertheless, some authors argue that preventive MN excision is not rational $[4,16]$ and propose that noninvasive screening should be actively promoted instead, including manual dermoscopy, sequential digital dermoscopy, computer -aided diagnosis, total body photography, highfrequency ultrasonography, reflectance confocal microscopy, multiphoton tomography, electrical impedance spectroscopy, Raman spectroscopy, and quantitative dynamic infrared imaging [13].

Zink et. al compared the results of the analysis of dermoscopy images with clinical data and histopathology findings. Dermoscopy images were taken in 26 patients using a mobile phone and a Handyscope optical instrument. Physical examinations and dermoscopy were performed by 5 dermatologists who worked independently of each other. The results were compared in terms of diagnostic accuracy, differential diagnosis and management strategies. The concordance of diagnoses was $92.3 \%$, whereas the concordance of recommended management strategies was $76.9 \%$. Of 6 histologically confirmed diagnoses, $66.7 \%$ were established based on dermoscopy images and a clinical examination. The authors concluded that digital dermoscopy microimages of individual lesions, including $\mathrm{MN}$, combined with macrophotographs could be assessed qualitatively and that mobile digital dermoscopy could be a good alternative to a traditional dermatologic examination [20]. In our study, the results of $\mathrm{Al}$-based analysis of dermoscopy images coincided with histopathology findings in 74 (100\%) cases. An optical adapter for a smartphone and an accompanying mobile application are very practical. Al can assess the mole for malignancy in a matter of seconds. Importantly, the system can be used in telediagnostics, saving time for patients and doctors [21].

The existing noninvasive techniques for skin diagnostics cannot replace a histopathological examination. It takes a doctor two years to be properly trained and build up sufficient experience. In difficult cases, there is a risk of misinterpretation. $\mathrm{Al}$ is a good aid in the primary screening of $\mathrm{SN}$ and establishing an accurate diagnosis [22].
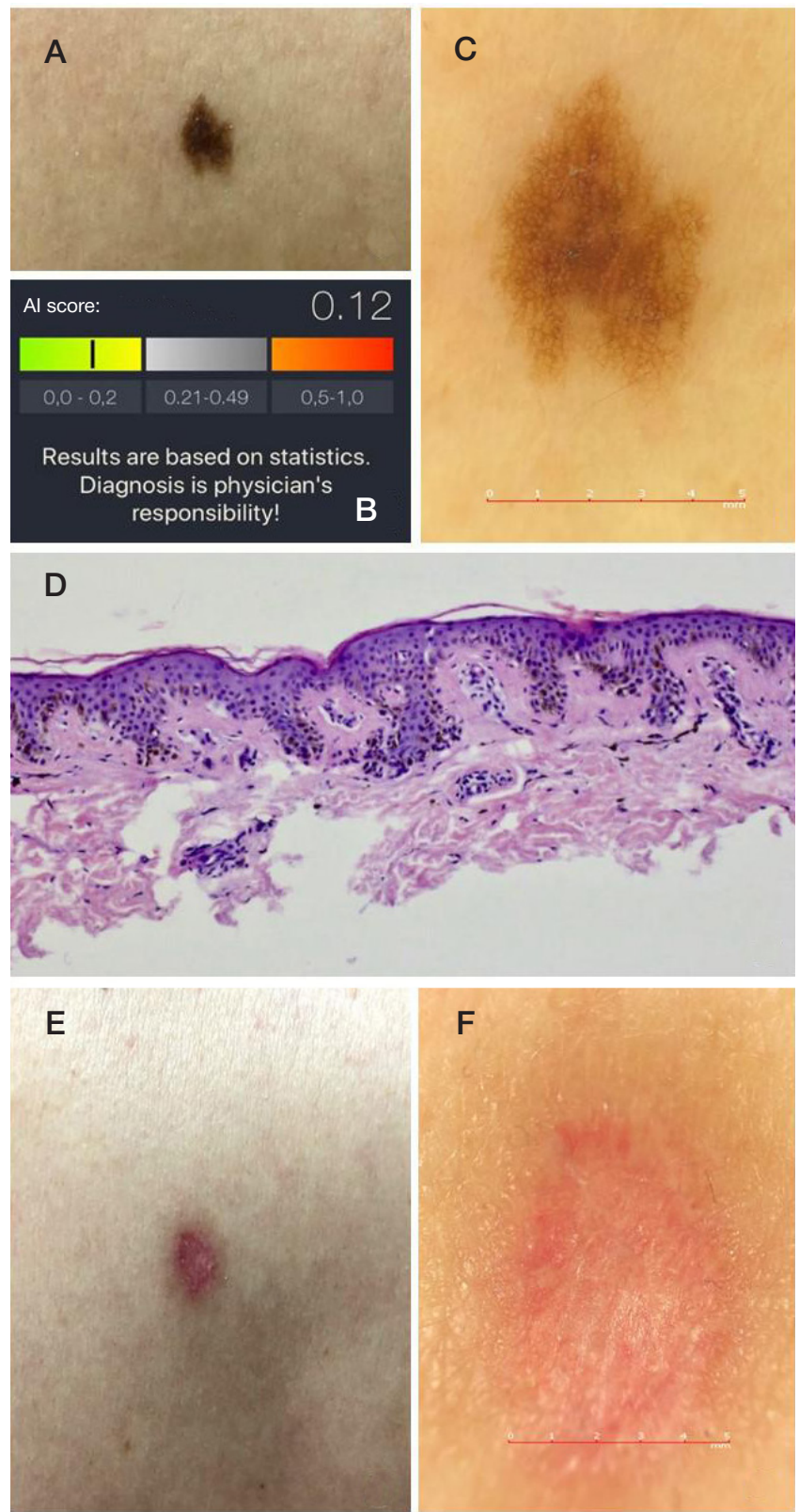

Fig. 1. Al in the assessment of $\mathrm{MN}$ for malignancy. A. A plain image of a melanocytic nevus. B. A malignancy score calculated by Al. C. A dermoscopy image at $\times 20$ magnification: a reticular dysplastic nevus with hyperpigmentation at the center. D. A histological slide (hematoxilin-eosin stainin, $\times 100$ magnification) showing the stratified squamous keratinized epithelium with areas of mild acanthosis. Multiple nevus cells adjacent to the epithelium are organized in a nesting pattern. Impression: D22. Borderline melanocytic nevus. ICD-O code: 8740/0. No nevoid cells are found at the margin of excision. D. Formation of a normotrophic scar. $\mathbf{E}$. A dermoscopy image of the normotrophic scar (at $\times 20$ magnification) 


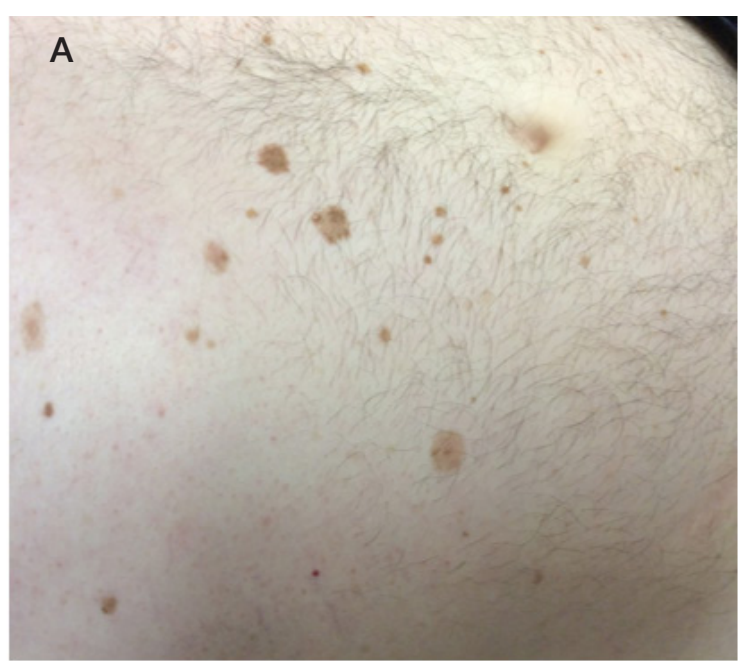

Fig. 2. A preoperative photo of $M M N$ on the abdomen. B. Postoperative scars

In Russia, MN screening strategies, including telescreening, are currently in development [23].

\section{CONCLUSION}

Patients with MMN must be closely monitored for possible malignization, which dictates the need for novel accurate

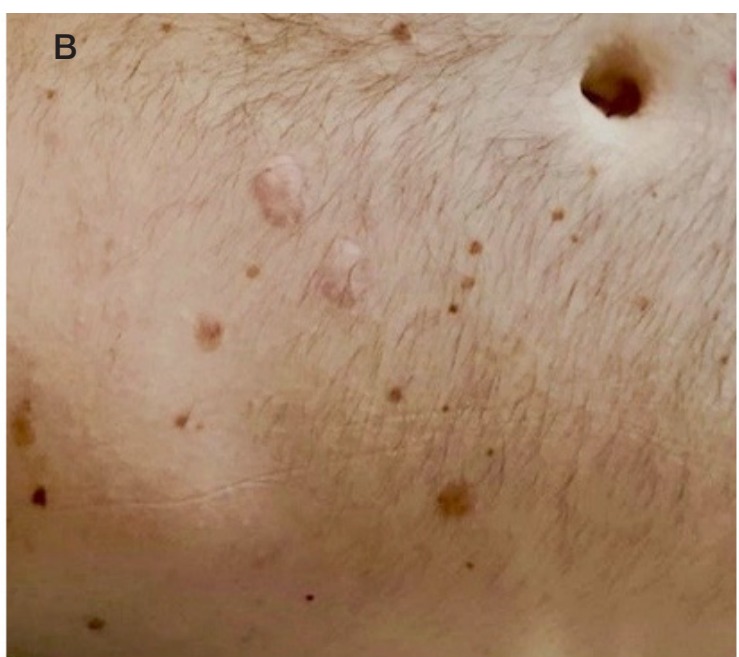

noninvasive diagnostic techniques. In this study, malignant MN were reliably detected using a smartphone-compatible optical instrument with 20x magnification and an Al-based mobile application for the analysis of dermoscopy images. Digitalization of the medical field and development of portable diagnostic instruments opens up new opportunities for providing medical care at a new hi-tech level.

\section{References}

1. Kaprin AD, Starinskij W, Petrova GV, redaktory. Zlokachestvennye novoobrazovanija $\vee$ Rossii $v 2018$ godu (zabolevaemost' smertnost'). M.: MNIOI im. P.A. Gercena - filial FGBU «NMIC radiologii» Minzdrava Rossii, 2019; 250 s. Russian.

2. Henley SJ, Ward EM, Scott S, Ma JM, Anderson RN, Firth AU, et al. Annual report to the nation on the status of cancer, part l: National cancer statistics. Cancer. 2020; 126 (10): 2225-49.

3. Kaprin AD, Starinskij W, Petrova GV, redaktory. Sostojanie onkologicheskö̈ pomoshhi naseleniju Rossii $\vee 2017$ godu. M.: $\mathrm{MNIOI}$ im. P.A. Gercena - filial FGBU «NMIC radiologii» Minzdrava Rossii, 2018; 236 s. Russian.

4. Kubanov AA, Sysoeva TA, Galljamova YuA, Bisharova AS, Mercalova IB. Algoritm obsledovanija pacientov s novoobrazovanijami kozhi. Lechashhij vrach. 2018; (3): 83-8. Russian.

5. Salamova IV, Mordovceva W, Lamotkin IA. Problema profilaktiki melanomy kozhi u pacientov s mnozhestvennymi nevusami. Klinicheskaja dermatologija i venerologija. 2014; 12 (2): 110-115. Russian.

6. Klinicheskie rekomendacii: melanoma kozhi i slizistyh obolochek (utv. Minzdravom Rossii) (17 ijulja, 2020). Dostupno po ssylke: https://melanomapro.ru/page/clinical-guidelines-melanoma_2020. Russian.

7. Salerni G, Carrera C, Lovatto L, Puig-Butille JA, Badenas C, Plana $E$, et al. Benefits of total body photography and digital dermatoscopy ("two-step method of digital follow-up") in the early diagnosis of melanoma in patients at high risk for melanoma. $J$ Am Acad Dermatol. 2012; 67 (1): e17-e27.

8. Romanova OA, Artemyeva NG, Yagubova EA, Rudakova IM, Marycheva VN, Veshchevailov AA. Principles of excisional biopsy of dysplastic nevus in outpatient settings. Onkologiya Zhurnal imeni PA Gertsena. 2016; 5 (1): 36-41.

9. Sergeev YuYu, Sergeev VYu, Mordovceva W. Dinamicheskoe nabljudenie za melanocitarnymi obrazovanijami pri pomoshhi dermatoskopii (obzor literatury). Medicinskij alfavit. 2020; (6): 66-71. Russian.

10. Sondermann W, Utikal J, Enk A, Schadendorf D, Klode J, Hauschild A, et al. Prediction of melanoma evolution in

melanocytic nevi via artificial intelligence: A call for prospective data. Eur J Cancer. 2019; 119: 30-4.

11. Hekler A, Utikal J, Enk A, Hauschild A, Weichenthal M, Maron RC, et al. Superior skin cancer classification by the combination of human and artificial intelligence. Eur J Cancer. 2019; 120: 114-121.

12. Glotsos D, Kostopoulos S, Lalissidou S, Sidiropoulos K, Asvestas P, Konstandinou C, et al. Design of a decision support system, trained on GPU, for assisting melanoma diagnosis in dermatoscopy images. Journal of Physics: Conference Series. 2015; 633: 012079.

13. Grajdeanu I, Vata D, Statescu L, Popescu I, Porumb-Andrese E, Patrascu A, et al. Use of imaging techniques for melanocytic naevi and basal cell carcinoma in integrative analysis (Review). Exp Ther Med. 2020: 78-86.

14. Doukas C, Stagkopoulos P, Maglogiannis I. Skin lesions image analysis utilizing smartphones and cloud platforms. Mobile Health Technologies. 2015; 1256: 435-458.

15. Lott J, Boudreau D, Barnhill R, Weinstock MA, Knopp E, Piepkorn MW, et al. Population-Based Analysis of Histologically Confirmed Melanocytic Proliferations Using Natural Language Processing. JAMA Dermatol. 2018; 154 (1): 24-9.

16. Emiroglu N, Sallahoglu K, Cengiz F, Cemil B, Onsun N. Three years dermoscopic follow-up of atypical nevi. Dermatol Ther. 2020; 33 (1): e13205.

17. Haenssle H, Mograby N, Ngassa A, Buhl T, Emmert S, Schön MP, et al. Association of Patient Risk Factors and Frequency of NevusAssociated Cutaneous Melanomas. JAMA Dermatol. 2016; 152 (3): 291-298.

18. Melamed R, Aydin I, Rajan G, Phelps R, Silvers DN, Emmett $\mathrm{KJ}$, et al. Genomic Characterization of Dysplastic Nevi Unveils Implications for Diagnosis of Melanoma. Journal of Investigative Dermatology. 2017; 137 (4): 905-909.

19. Woltsche N, Schmid-Zalaudek K, Deinlein T, Rammel K, HofmannWellenhof R, Zalaudek I. Abundance of the benign melanocytic universe: Dermoscopic-histopathological correlation in nevi. J Dermatol. 2017; 44 (5): 499-506.

20. Zink A, Kolbinger A, Leibl M, Suarez I, Gloning J, Merkel C, et al. 
Teledermoscopy by mobile phones. Reliable help in the diagnosis of skin lesions? Der Hautarzt. 2017; 68 (11): 890-895.

21. Wu X, Oliveria S, Yagerman S, Chen L, Defazio J, Braun R, et al. Feasibility and Efficacy of Patient-Initiated Mobile Teledermoscopy for Short-term Monitoring of Clinically Atypical Nevi. JAMA Dermatol. 2015; 151 (5): 489-496.
22. Gaydina TA, Dvornikov AS, Skripkina PA. Case report: removal of a proliferating pilomatricoma with a $\mathrm{CO}_{2}$ laser. Bulletin of Russian state medical university. 2019; 6: 110-113. Russian.

23. Demidov LV, Sinel'nikov IE, Baryshnikov KA, Utjashev IA, Nazarova W. Perspektivy skrininga melanomy kozhi $\vee$ Rossii. Vestnik FGBU «RONC im. N.N. Blohina». 2017; 28 (1-2): 28-35.

\section{Литература}

1. Каприн А. Д., Старинский В. В., Петрова Г. В., редакторы. Злокачественные новообразования в России в 2018 году (заболеваемость и смертность). М.: МНИОИ им. П.А. Герцена филиал ФГБУ «НМИЦ радиологии» Минздрава России, 2019; $250 \mathrm{c.}$

2. Henley SJ, Ward EM, Scott S, Ma JM, Anderson RN, Firth AU, et al. Annual report to the nation on the status of cancer, part I: National cancer statistics. Cancer. 2020; 126 (10): 2225-49.

3. Каприн А. Д., Старинский В. В., Петрова Г. В., редакторы. Состояние онкологической помощи населению России в 2017 году. М.: МНИОИ им. П.А. Герцена - филиал ФГБУ «НМИЦ радиологии» Минздрава России, 2018; 236 с.

4. Кубанов А. А., Сысоева Т. А., Галлямова Ю. А., Бишарова А. С., Мерцалова И. Б. Алгоритм обследования пациентов с новообразованиями кожи. Лечащий врач. 2018; (3): 83-88.

5. Саламова И. В., Мордовцева В. В., Ламоткин И. А. Проблема профилактики меланомы кожи у пациентов с множественными невусами. Клиническая дерматология и венерология. 2014; 12 (2): 110-115.

6. Клинические рекомендации: меланома кожи и слизистых оболочек (утв. Минздравом России) (17 июля, 2020). Доступно по ссылке: https://melanomapro.ru/page/clinicalguidelines-melanoma_2020.

7. Salerni G, Carrera C, Lovatto L, Puig-Butille JA, Badenas C, Plana $\mathrm{E}$, et al. Benefits of total body photography and digital dermatoscopy ("two-step method of digital follow-up") in the early diagnosis of melanoma in patients at high risk for melanoma. $J$ Am Acad Dermatol. 2012; 67 (1): e17-e27.

8. Романова О. А., Артемьева Н. Г., Ягубова Э. А., Рудакова И. М., Марычева В. Н., Вещевайлов А. А. Принципы эксцизионной биопсии диспластического невуса в амбулаторных условиях. Онкология. Журнал им. П.А. Герцена. 2016; 5 (1): 36-41.

9. Сергеев Ю. Ю., Сергеев В. Ю., Мордовцева В. В. Динамическое наблюдение за меланоцитарными образованиями при помощи дерматоскопии (обзор литературы). Медицинский алфавит. 2020; (6): 66-71.

10. Sondermann W, Utikal J, Enk A, Schadendorf D, Klode J, Hauschild A, et al. Prediction of melanoma evolution in melanocytic nevi via artificial intelligence: A call for prospective data. Eur J Cancer. 2019; 119: 30-4.

11. Hekler A, Utikal J, Enk A, Hauschild A, Weichenthal M, Maron $\mathrm{RC}$, et al. Superior skin cancer classification by the combination of human and artificial intelligence. Eur J Cancer. 2019; 120: 114121.

12. Glotsos D, Kostopoulos S, Lalissidou S, Sidiropoulos K,
Asvestas P, Konstandinou C, et al. Design of a decision support system, trained on GPU, for assisting melanoma diagnosis in dermatoscopy images. Journal of Physics: Conference Series. 2015; 633: 012079

13. Grajdeanu I, Vata D, Statescu L, Popescu I, Porumb-Andrese E, Patrascu A, et al. Use of imaging techniques for melanocytic naevi and basal cell carcinoma in integrative analysis (Review). Exp Ther Med. 2020: 78-86.

14. Doukas C, Stagkopoulos P, Maglogiannis I. Skin lesions image analysis utilizing smartphones and cloud platforms. Mobile Health Technologies. 2015; 1256: 435-458.

15. Lott J, Boudreau D, Barnhill R, Weinstock MA, Knopp E, Piepkorn MW, et al. Population-Based Analysis of Histologically Confirmed Melanocytic Proliferations Using Natural Language Processing. JAMA Dermatol. 2018; 154 (1): 24-9.

16. Emiroglu N, Sallahoglu K, Cengiz F, Cemil B, Onsun N. Three years dermoscopic follow-up of atypical nevi. Dermatol Ther. 2020; 33 (1): e13205.

17. Haenssle H, Mograby N, Ngassa A, Buhl T, Emmert S, Schön MP, et al. Association of Patient Risk Factors and Frequency of NevusAssociated Cutaneous Melanomas. JAMA Dermatol. 2016; 152 (3): 291-298.

18. Melamed R, Aydin I, Rajan G, Phelps R, Silvers DN, Emmett KJ, et al. Genomic Characterization of Dysplastic Nevi Unveils Implications for Diagnosis of Melanoma. Journal of Investigative Dermatology. 2017; 137 (4): 905-909.

19. Woltsche N, Schmid-Zalaudek K, Deinlein T, Rammel K, HofmannWellenhof R, Zalaudek I. Abundance of the benign melanocytic universe: Dermoscopic-histopathological correlation in nevi. $J$ Dermatol. 2017; 44 (5): 499-506.

20. Zink A, Kolbinger A, Leibl M, Suarez I, Gloning J, Merkel C, et al. Teledermoscopy by mobile phones. Reliable help in the diagnosis of skin lesions? Der Hautarzt. 2017; 68 (11): 890-895.

21. Wu X, Oliveria S, Yagerman S, Chen L, Defazio J, Braun R, et al. Feasibility and Efficacy of Patient-Initiated Mobile Teledermoscopy for Short-term Monitoring of Clinically Atypical Nevi. JAMA Dermatol. 2015; 151 (5): 489-496.

22. Гайдина Т. А., Дворников А. С., Скрипкина П. А. Клинический случай: удаление пролиферирующей пиломатриксомы $\mathrm{CO}_{2}$-лазером. Вестник Российского государственного медицинского университета. 2019; 6: 110-113.

23. Демидов Л. В., Синельников И. Е., Барышников К. А., Утяшев И. А., Назарова В. В. Перспективы скрининга меланомы кожи в России. Вестник ФГБУ «РОНЦ им. Н. Н. Блохина», 2017; 28 (1-2): 28-35. 